\title{
Putative antiviral activity in hemolymph from adult Pacific oysters, Crassostrea gigas
}

\author{
Cécile Olicarda ${ }^{b, c}$, Tristan Renault $^{b}$, Corinne Torhy ${ }^{d}$, Abdenour Benmansour $^{d}$ \\ and Nathalie Bourgougnon ${ }^{\mathrm{a}_{*}}$
}

\author{
'Laboratoire de Biotechnologie et Chimie Marines, EA 2594, Université de Bretagne Sud, Campus de Tohannic, \\ Centre de recherche Yves Coppens, 56017 Vannes, France \\ ${ }^{\mathrm{b}}$ IFREMER, Laboratoire de Génétique et Pathologie, 17390 La Tremblade, France \\ 'Laboratoire de Biologie et Environnement Marins, Université de La Rochelle, 17042 La Rochelle, France \\ dINRA, Unité de Virologie et Immunologie Moléculaires, 78352 Jouy-en-Josas, France
}

*: Corresponding author : Tel.: +33 29701 71 55; fax: +33 2970170 71. nathalie.bourgougnon@univ-ubs.fr

\begin{abstract}
Innate, non-specific resistance mechanisms are important to pathogens, particularly for delaying virus replication at the onset of infection. Innate immunity constitutes the first line of defense in vertebrates and is the only one in invertebrates. Little is known about possible antiviral substances in invertebrates. The present work concerns a study of antiviral substances in hemolymph from adult Crassostrea gigas oysters. Despite the detection of cytotoxicity in fresh filtered hemolymph for both mammalian (CC50: $750 \mu \mathrm{g} / \mathrm{ml}$ ) and fish cells (CC50: $>2000 \mu \mathrm{g} / \mathrm{ml}$ for EPC cells and $345 \mu \mathrm{g} / \mathrm{ml}$ for RTG-2 cells), an antiviral substance was detected. Fresh filtered hemolymph was capable of inhibiting the replication of herpes simplex virus type 1 in vitro at an EC50 of $425 \mu \mathrm{g} / \mathrm{ml}$ (total proteins) and the replication of infectious pancreatic necrosis virus in EPC and RTG-2 cells at 217 and $156 \mu \mathrm{g} / \mathrm{ml}$ (total proteins), respectively.
\end{abstract}

Keywords: Oyster; Crassostrea gigas; Antiviral defense; HSV-1; IPNV; VHSV; Hemolymph 


\section{Introduction}

Several molecules extracted from marine invertebrates, including bivalves, possess broad spectrum anti-microbial activities, affecting the growth of bacteria, fungi and yeasts (Nakamura et al., 1988; Mitta et al., 2000; Zasloff, 2002). However, there is relatively little information available on the antiviral defense mechanisms of bivalves. Antiviral substances (paolin I and II) have been reported in clam, Mya arenaria (Li et al., 1972 ; Prescott et al., 1966), and in vitro assays were used to detect a neutralising activity against T3 coliphage in haemolymph from the Pacific oyster, Crassostrea gigas (Bachère et al., 1990). A peptide that inhibits HIV-1 protease was also isolated from C. gigas hydrolysate (Lee and Maruyama, 1998).

The first bivalve virus was reported in adult eastern oysters, $C$. virginica, and had a particle morphology indicating membership of the family Herpesviridae (Farley et al., 1972). Since 1991, high mortalities of $C$. gigas larvae and juveniles have been observed regularly in association with herpesvirus infections in countries around the world (Renault et al., 2001; Arzul and Renault, 2002). Adult oysters appear less sensitive to herpesvirus infections. However, although abnormal mortality has not occurred among C. gigas adults in France, the presence of viral DNA was demonstrated in adults of normal appearance (Arzul et al., 2002). Thus, like other herpesviruses, ostreid herpesvirus 1 (OsHV-1) seems to be able to persist in adult $C$. gigas, which are evidently able to maintain effective immunity. Thus, C. gigas appears to be an appropriate invertebrate species in which to study antiviral innate immunity. The present study led to the detection of an activity in C. gigas acellular haemolymph that inhibits growth of a mammalian virus, herpes simplex virus type 1 (HSV-1; family Herpesviridae) in vitro at concentrations causing minimum cytotoxicity. Antiviral activity was also evaluated on fish cell lines infected by two fish viruses, viral haemorrhagic septicaemia virus (VHSV, family Rhabdoviridae) and infectious pancreatic necrosis virus (IPNV, family Birnaviridae).

\section{Materials and Methods}

\subsection{Sources of oysters and haemolymph collection}

Three year-old Pacific oysters, C. gigas, were obtained from shellfish farms in the Marennes-Olèron Bassin (Charente Maritime, France) on the French Atlantic coast. Oysters were collected during the winter of 2002-3 and the summer of 2003. Haemolymph was collected from the pericardial cavity using a sterile syringe $\left(1 \mathrm{ml}, 23 \mathrm{G}, \mathrm{n}^{\circ} 16\right.$, Terumo). An acellular fraction was obtained by filtering the crude haemolymph through a $0.22 \mu \mathrm{m}$ sterile filter. The filtered material was stored in aliquots at $-80^{\circ} \mathrm{C}$. Total concentrations of proteins in the extracts were determined by the Lowry method (Lowry et al., 1951).

\subsection{Cells and viruses}

African green monkey kidney cells (Vero, ATCC CCL-81) were grown in Eagle's minimum essential medium (MEM, Eurobio) supplemented with $8 \%$ fetal calf serum (FCS, Eurobio) and 1\% PCS (10000 IU/ml penicillin, $25000 \mathrm{IU} / \mathrm{ml}$ colimycin, $10 \mathrm{mg} / \mathrm{ml}$ streptomycin; Sigma). HSV-1 (wild type strain 17, sensitive to acyclovir) was obtained from Pr. Ingrand (Hôpital A. Béclère, Reims, France). 
The fibroblastic RTG-2 cell line, derived from rainbow trout (Oncorhyncus mykiss) gonad tissue, and the epithelial EPC (Cyprini epithelioma papulosum) cell line derived from carp, Cyprinus carpio, were incubated at $14^{\circ} \mathrm{C}$ in Eagle's Glasgow medium (MEM, BioWhittaker) supplemented with $2 \%$ FCS and antibiotics (100 IU/ml penicillin, $0.1 \mathrm{~g} / \mathrm{ml}$ streptomycin ARE THESE FINAL CONCENTRATIONS?). IPNV (VR 299 strain) and VHSV (07.71 strain) were propagated in RTG-2 and EPC cells, RESPECTIVELY? aliquoted and stored at $-80^{\circ} \mathrm{C}$.

Virus titers were estimated from cytopathogenicity according to the Reed and Muench (1938) dilution method, and expressed as $50 \%$ infectious doses per milliliter ( $\left.\mathrm{ID}_{50} / \mathrm{ml}\right)$. The HSV -1 stock had a titre of $2 \times 10^{5.80} \mathrm{ID}_{50} / \mathrm{ml}$. The IPNV and VHSV stocks had titres of $2 \times 10^{5.26}$ $\mathrm{ID}_{50} / \mathrm{ml}$.

\subsection{Cytotoxicity assay by cell viability}

Using the Vero cell/HSV-1 model, cytotoxicity was evaluated by incubating cellular suspensions $\left(3.5 \times 10^{5}\right.$ cells $\left./ \mathrm{ml}\right)$ with various dilutions (total protein concentration from 200 to $1100 \mu \mathrm{g} / \mathrm{ml}$, 4 wells per concentration) of oyster haemolymph in 96-well plates (48 hours, $37^{\circ} \mathrm{C}, 5 \% \mathrm{CO}_{2}$ ) in Eagle's MEM containing 8\% FCS. The cells were examined daily under a phase-contrast microscope to determine the minimum concentration of haemolymph that induced alterations in cell morphology, including swelling, shrinkage, granularity and detachment. Cytotoxicity by cell viability was tested using the neutral red dye method (McLaren et al., 1983). Optical density (OD) was measured at $540 \mathrm{~nm}$ using a spectrophotometer (SpectraCount ${ }^{\mathrm{TM}}$, Packard). The 50\% cytotoxic concentration $\left(\mathrm{CC}_{50}\right.$ ) was defined as the concentration that reduced the OD of treated cells to $50 \%$ of that of untreated cells. $\mathrm{CC}_{50}$ values were expressed as the percentage of destruction (\%D): [(ODc)C (ODc)MOCK / (ODc)C] x 100. (ODc)C and (ODc)MOCK were the OD values of the untreated cells and treated cells, respectively.

Using fish models, cytotoxicity was evaluated by incubating RTG-2 cells $\left(4.75 \times 10^{5}\right.$ cells $/ \mathrm{ml})$ or EPC cells $\left(12.5 \times 10^{5}\right.$ cells $\left./ \mathrm{ml}\right)$ with various dilutions of oyster haemolymph (total protein concentration from 70 to $550 \mu \mathrm{g} / \mathrm{ml}$, 2 wells per concentration) in 96-well plates (48 hours at $14^{\circ} \mathrm{C}$ ) in Eagle's MEM containing 2\% FCS. Cytotoxicity was measured as absorbance at $590 \mathrm{~nm}$ after incubation for 45 minutes in crystal violet (Renault et al., 1991). $\mathrm{CC}_{50}$ values were derived as described above.

\subsection{Antiviral assays by cell viability}

Using the Vero cell/HSV-1 model, $100 \mu \mathrm{l}$ of cellular suspension $\left(3.5 \times 10^{5}\right.$ cells $\left./ \mathrm{ml}\right)$ in Eagle's MEM containing 8\% FCS was incubated with $50 \mu \mathrm{l}$ of a dilution of filtered haemolymph (total protein concentration from 200 to $1100 \mu \mathrm{g} / \mathrm{ml}$ ) in 96 well-plates (48 hours, $37^{\circ} \mathrm{C}, 5 \% \mathrm{CO}_{2}$ ). Three replicates were infected using $50 \mu \mathrm{l}$ of medium or a virus suspension at a MOI of $0.001 \mathrm{ID}_{50} /$ cells. After incubation, antiviral activity was evaluated by the neutral red dye method. The antiherpetic compound acyclovir (9-(2-hydroxyethoxymethyl)guanine) was used as reference inhibitor. The $50 \%$ effective antiviral concentration $\left(\mathrm{EC}_{50}\right)$ was expressed as the concentration that achieved $50 \%$ protection of virus-infected cells from virus-induced destruction. The OD was related directly to the percentage of viable cells, which was inversely related to the cytopathic effect (CPE) THE MEANING OF THE ORIGINAL SENTENCE WAS NOT CLEAR. The linear regression was determined for each assay on the basis of cell controls (0\% CPE) and virus controls (100\% CPE). Data were expressed as a percentage of protection (\%P): [((ODt)virus - (ODc)virus) / ((ODc)MOCK (ODc)virus)] x 100. (ODt)virus was the OD of the test sample, (ODc)virus was the OD of the 
virus control (no haemolymph), and (ODc)MOCK was the OD of the mock-infected control (Langois et al., 1986).

Using fish RNA viruses, $50 \mu \mathrm{l}$ of cellular suspension (RTG-2, $4.75 \times 10^{5}$ cells $/ \mathrm{ml}$ or EPC, $12.5 \times 10^{5}$ cells $/ \mathrm{ml}$ ) in Eagle's MEM containing 2\% FCS was incubated with $25 \mu \mathrm{l}$ of various dilutions of oyster haemolymph (70 to $550 \mu \mathrm{g} / \mathrm{ml}$ ) in 96 well-plates (48 hours, $14^{\circ} \mathrm{C}$ ). At each concentration, two replicates were infected by $25 \mu \mathrm{l}$ of medium or virus suspension at a MOI of $0.01 \mathrm{ID}_{50} /$ cell. After incubation, antiviral activity was evaluated by the crystal violet method. ODs were determined at $590 \mathrm{~nm}$, and $\mathrm{EC}_{50}$ values were calculated as described above.

\subsection{Mechanism of action}

Virucidal assay. A virus suspension containing $0.001 \mathrm{ID}_{50} / \mathrm{cell}$ of HSV-1 or $0.01 \mathrm{ID}_{50} / \mathrm{cell}$ of IPNV was incubated with an equal volume of medium with or without haemolymph dilutions (70 to $550 \mu \mathrm{g} / \mathrm{ml}$ of total proteins) for $1 \mathrm{~h}$ at $37^{\circ} \mathrm{C}$ for $\mathrm{HSV}-1$ and overnight at $14{ }^{\circ} \mathrm{C}$ for IPNV. One hundred $\mu \mathrm{l}$ of mixed suspension was then added to $100 \mu \mathrm{l}$ of cellular suspension ( $3 \times 10^{5}$ Vero cells $/ \mathrm{ml}$ or $4.75 \times 10^{5} \mathrm{RTG}-2$ cells $/ \mathrm{ml}$ ) in culture medium (Damonte et al., 1994, 1996; Bergé et al., 1999). After incubating for 48 hours, the virucidal effect was determined using the neutral red dye method for HSV-1 and the crystal violet method for IPNV.

Effect before infection. To determine whether a cellular anti-viral state could be induced by haemolymph, cells were incubated with haemolymph (24 hours, $37^{\circ} \mathrm{C}, 5 \% \mathrm{CO}_{2}$ ) and were then washed with PBS. Cells were inoculated with virus and incubated for 48 hours $\left(37^{\circ} \mathrm{C}\right.$, 5\% $\mathrm{CO}_{2}$ ) (Damonte et al., 1994, 1996; Bergé et al., 1999). The effect on virus multiplication was determined by the neutral red dye method for HSV-1 and the crystal violet method for IPNV.

Effect of haemolymph addition time. Monolayers of Vero cells were inoculated with HSV1 at $0.001 \mathrm{ID}_{50} /$ cell, and haemolymph was added simultaneously or after $1,2,3$ or $5 \mathrm{~h}$ following infection. After $48 \mathrm{~h}$ of incubation, the effect on HSV-1 replication was determined by the neutral red dye method. RTG-2 cells were inoculated with IPNV at $0.01 \mathrm{ID}_{50} /$ cell. Haemolymph was added simultaneously or after 1, 2, 3 or $5 \mathrm{~h}$ following infection (Damonte et al., 1994, 1996; Bergé et al., 1999). After 48 h of incubation, the effect on IPNV replication was determined by the crystal violet method.

Virus adsorption assay. The inhibitory effect of haemolymph on virus adsorption was measured on confluent monolayers of Vero cells infected with HSV-1 at $0.001 \mathrm{ID}_{50} /$ cell, under different treatments (Damonte et al., 1994, 1996; Bergé et al., 1999). In treatment I, cells were exposed to HSV-1 in the presence of various haemolymph dilutions. After virus adsorption $\left(1 \mathrm{~h}\right.$ at $\left.4^{\circ} \mathrm{C}\right)$, cells were washed with PBS to remove both haemolymph and unadsorbed virus and further incubated with medium. In treatment II, cells were exposed to HSV-1 and after a virus adsorption period $\left(1 \mathrm{~h}\right.$ at $\left.4^{\circ} \mathrm{C}\right)$, unadsorbed virus was removed and cells were further incubated with the medium containing different concentrations of haemolymph. In treatment III, haemolymph was present both during and after the adsorption period. The effect on HSV-1 adsorption was determined after 2 days by the neutral red dye method. 
Figure 1: Putative anti-HSV-1 activity of filtered oyster haemolymph.

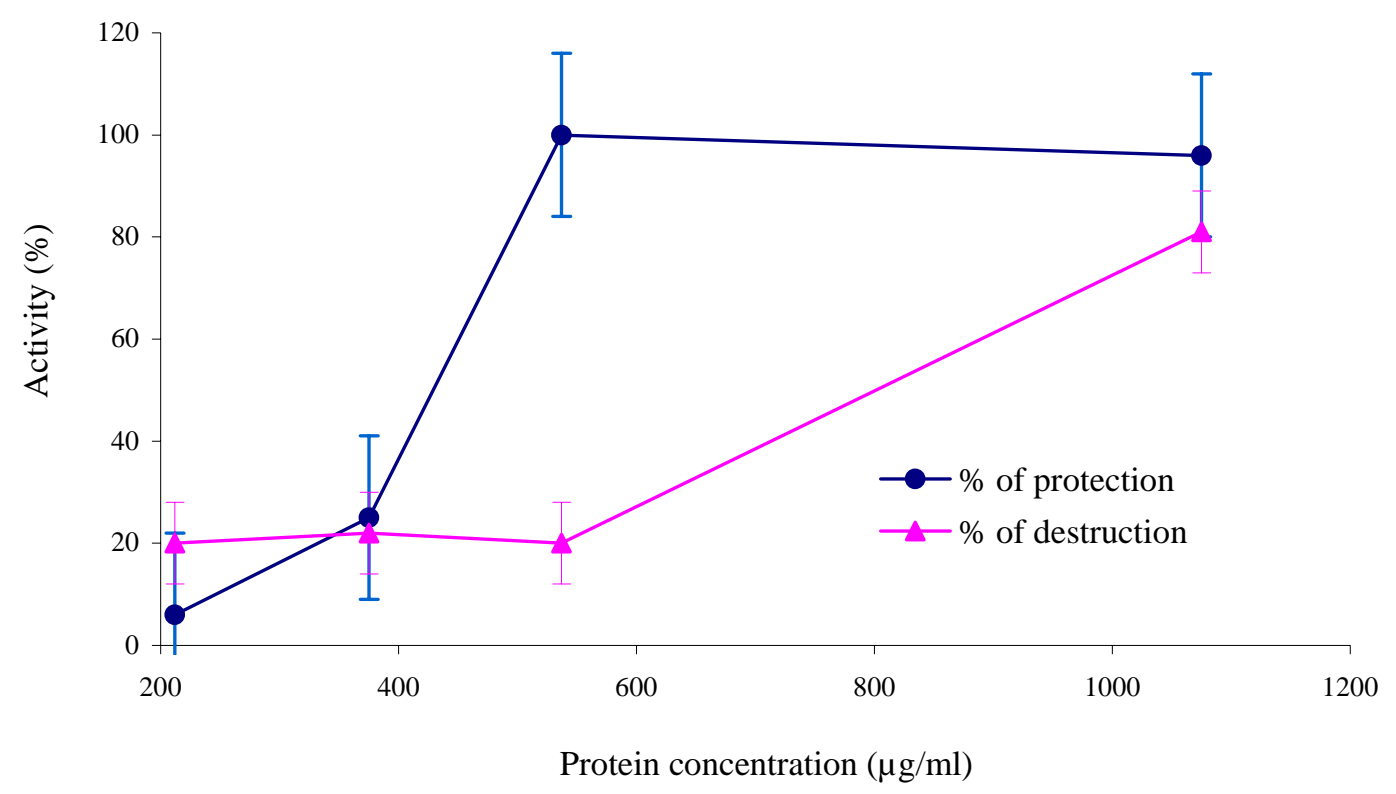

Figure 1 shows the antiviral and cytotoxic activities of acellular haemolymph observed after incubating for 48 hours a 96-well plate containing Vero cells infected by HSV-1 (MOI 0.001 $\mathrm{ID}_{50} /$ cell) with various concentrations of haemolymph. Vero cells are mammalian fibroblastic cells and HSV-1 is herpes simplex virus type 1.

Antiviral activity is expressed as the percentage of viable virus-infected cells (\% of protection). Cytotoxic activity is observed as the percentage of viable mock-infected cells (\% of destruction). The $50 \%$ effective antiviral concentration $\left(E_{50}\right)$ was $425 \mu \mathrm{g} / \mathrm{ml}$ of total protein. The $50 \%$ cytotoxic concentration $\left(\mathrm{CC}_{50}\right)$ was $750 \mu \mathrm{g} / \mathrm{ml}$ of total protein.

Evaluation was carried out three times.

Prescott et al. (1966) reported that molecules (paolins) from clams and oysters were active in vitro and in vivo against micro-organisms, including HSV-1. Moreover, Lee and Maruyama (1998) isolated a peptide from a hydrolysate of the Pacific oyster, C. gigas, which inhibited HIV-1 protease. Previous studies hardly suggested that broadly non-specific antiviral substances are present in tissue extracts from crustaceans, including shrimp, crayfish and crab (Pan et al., 2000) THE ORIGINAL MEANING IS NOT CLEAR AND I HAVE NOT CHANGED IT. Although the selective index (1.76) (Table 1) is low, this study highlights the presence of an antiviral activity in adult oyster haemolymph. 
Table 1: Haemolymph activity $\left(\mathrm{EC}_{50}\right.$ and $\left.\mathrm{CC}_{50}\right)$ on fish viruses.

\section{EPC/IPNV}

EPC/VHSV

RTG-2/VHSV

346.2

2.21
$>2000$

$>2000$
$<1.00$
$>2000$

346.2

HSV-1/Vero

425

750

$<0.17$

1.76

Table 1 shows the antiviral and cytotoxic activities of acellular haemolymph observed after incubating for 48 hours a 96-well plate containing fish cells infected by fish viruses in the presence of different concentrations of haemolymph. EPC are carp epithelial cells, RTG-2 are rainbow trout gonad fibroblastic cells, and Vero are mammalian (simian) fibroblastic cells. IPNV is infectious pancreatic necrosis virus, VHSV is viral haemorrhagic septicaemia virus, and HSV-1 is herpes simplex virus type 1 . Results are expressed as $\mathrm{EC}_{50}$ (the $50 \%$ antiviral effective concentration), $\mathrm{CC}_{50}$ (the $50 \%$ cytotoxic concentration) and SI, the selective index $\left(\mathrm{CC}_{50} / \mathrm{EC}_{50}\right)$.

Evaluation was carried out in triplicate.

A first approach to determining the mode of action of haemolymph was initiated by carrying out different treatments on the HSV-1/Vero model, and the results are shown in Table 2. Results are expressed as percentage of viable virus-infected cells (\% of protection: \%P) and as the percentage of viable mock-infected cells (\% of destruction: \%D).

Hm : Haemolymph

Addition time : Hm was added simultanously, or 1, 2, 3 or 5 hours after virus inoculation

Treatment I : Virus + cells $+\mathrm{Hm} \rightarrow\left(1 \mathrm{~h}, 4^{\circ} \mathrm{C}\right) \rightarrow$ PBS $\rightarrow$ cells

Treatment II : Virus + cells $\rightarrow\left(1 \mathrm{~h}, 4^{\circ} \mathrm{C}\right) \rightarrow$ PBS $\rightarrow$ cells $+\mathrm{Hm}$

Treatment III : Virus + cells $+\mathrm{Hm} \rightarrow\left(1 \mathrm{~h}, 4^{\circ} \mathrm{C}\right) \rightarrow$ PBS $\rightarrow$ cells $+\mathrm{Hm}$

Effect before infection: cells and $\mathrm{Hm}$ were incubated for $24 \mathrm{~h}$ at $37^{\circ} \mathrm{C}$ before virus inoculation

Virucidal assay : virus and $\mathrm{Hm}$ were incubated for $1 \mathrm{~h}$ at $37^{\circ} \mathrm{C}$ before addition to cell suspension

Evaluation was carried out in triplicate.

\subsection{Antiviral activity against fish viruses}

The evaluation of antiviral activity in fish models provided complementary information. The $\mathrm{CC}_{50}$ of filtered haemolymph on EPC cells was greater than $2000 \mu \mathrm{g} / \mathrm{ml}$, but values reached $346.2 \mu \mathrm{g} / \mathrm{ml}$ of proteins on RTG-2 cells (Table 1 ).

No inhibition of VHSV growth was observed on EPC and RGT-2 cells (Table 1). However, haemolymph had an antiviral effect against IPNV (a non-enveloped RNA virus) in fibroblastic and epithelial cells. It completely inhibited (100\% of protection) the growth of IPNV in RTG-2 cells at a total protein concentration of $137.5 \mu \mathrm{g} / \mathrm{ml}$ THIS IS NOT 
CONSISTENT WITH THE DATA IN TABLE 1, AS THIS VALUE IS LESS THAN THE $\mathrm{EC}_{50}$. The effect was greater in fibroblastic cells $\left(\mathrm{EC}_{50} 156.4 \mu \mathrm{g} / \mathrm{ml}\right)$ than in epithelial cells (EC $\left.\mathrm{E}_{50} 217.3 \mu \mathrm{g} / \mathrm{ml}\right)$.

The results using fish models confirm the presence of an antiviral activity in adult oyster haemolymph. The selective index in fish models (2.21 in the RTG-2/IPNV model and 9.20 in the EPC/IPNV model) was greater than that in the mammalian model (1.76). In contrast to the epithelial fish cell line (EPC), haemolymph produced major cytotoxicity on both fibroblastic cell lines (RTG-2 and Vero cells), with $\mathrm{CC}_{50}$ values of 346.2 and $750 \mu \mathrm{g} / \mathrm{ml}$, respectively. $\mathrm{EC}_{50}$ values in the IPNV/RTG-2 and HSV-1/Vero models were close to the $\mathrm{CC}_{50}$ values, and thus it is difficult to differentiate cytotoxicity from an antiviral effect. Nevertheless, an effect was discerned with models. THE LAST TWO SENTENCES WERE NOT CLEAR, AND I HAVE GUESSED A BIT. Filtered haemolymph did not inhibit VHSV, an enveloped RNA virus, but exerted an antiviral activity against IPNV, a non-enveloped RNA virus. IS THIS OK? Moreover, no cytotoxic effect was detected on EPC cells.

Antiviral substances from invertebrates have been reported previously. Halocyamins A IS THIS NAME RIGHT AND DOES IT HAVE TO BE A PLURAL? (Azumi et al., 1990) isolated from haemocytes of ascidie WHAT IS THIS? induced an inhibition of IPNV growth in RTG-2 cells for $100 \mu \mathrm{g} / \mathrm{ml}$ of pure peptide. Moreover, Pan et al. (2000) demonstrated that crustacean tissue extracts from crab, shrimp and crayfish are broadly antiviral against a variety of viruses, including DNA and enveloped and non-enveloped RNA viruses.

\subsection{First approach to the mechanism of action}

A first approach to determining the mode of action of haemolymph was initiated by carrying out different treatments in the HSV-1/Vero and IPNV/RTG-2 models. WHERE ARE THE DATA FOR IPNV?

Virucidal assay. Preincubation of the virus with haemolymph did not protect Vero cells against HSV-1 (Table 2). IPNV suspension mixed for one night at $14^{\circ} \mathrm{C}$ with haemolymph did not protect RTG-2 cells against infection. These results indicate that haemolymph does not irreversibly neutralise HSV-1 or IPNV. 
Table 2: A first approach to determining the mechanism of action of filtered oyster haemolymph.

\begin{tabular}{lcccc}
\hline \hline \multicolumn{1}{c}{ Mechanisms } & & $\% \mathrm{P}$ & $\% \mathrm{D}$ & $\mathrm{EC}_{50}$ control \\
\hline \hline \multicolumn{1}{c}{ Virucidal assay } & $48 \mathrm{~h}$ & 0.00 & 30.00 & 0.27 \\
\hline Effect before infection & $48 \mathrm{~h}$ & $0.00^{2}$ & 35.00 & $>2.00$ \\
\hline Effect of time of & $0 \mathrm{~h}$ & $89.00_{( \pm 21)}$ & $20.00_{( \pm 4)}$ & 0.32 \\
haemolymph addition & $1 \mathrm{~h}$ & $98.00_{( \pm 4)}$ & $38.00_{( \pm 24)}$ & 0.32 \\
& $2 \mathrm{~h}$ & $100.00_{( \pm 0)}$ & $33.00_{( \pm 0)}$ & 0.40 \\
& $3 \mathrm{~h}$ & $0.00_{( \pm 4)}$ & $33.00_{( \pm 1)}$ & 0.45 \\
& $5 \mathrm{~h}$ & $0.00_{( \pm 0)}$ & $41.00_{( \pm 3)}$ & 0.53 \\
\hline Virus adsorption assay & Treatment I & 35.50 & 16.00 & 0.90 \\
& Treatment II & 74.00 & 35.00 & 0.14 \\
& Treatment III & 98.50 & 44.00 & 0.16 \\
\hline \hline
\end{tabular}

Effect before infection. Vero cells were not protected from HSV-1 infection when haemolymph was present only before virus infection (Table 2). The haemolymph did not induce a durable antiviral state in the target cells.

Effect of haemolymph addition time. Vero cells were optimally protected (89-100\%) when haemolymph was added at 0-2 hours after infection (Table 2). After 3 hours, antiviral activity decreased dramatically. The cytotoxicity increased from 20 to $41 \%$ between $0-5$ hours (Table 2). In comparison, the $\mathrm{EC}_{50}$ of acyclovir increased from 0.32 to $0.53 \mu \mathrm{g} / \mathrm{ml}$ between $0-5$ hours (Table 2). Similar results using haemolymph were observed in the fish model (data not shown).

Virus adsorption assay. With treatment I, a low antiviral activity (35\% of protection) and $16 \%$ of cell destruction were reported. With treatment II, a high percentage of cell protection (74\%) was observed. With treatment III, a higher percentage of protection than in treatment II (98\%) was reported (Table 2). Vero cells were not protected from HSV-1 infection when haemolymph was present before infection (Table 2).

Haemolymph did not exert a virucidal effect on HSV-1. Moreover, virus inhibition required the simultaneous presence of haemolymph, virus and cells, suggesting the reversible nature of the inhibition. The antiviral activity might be mediated throughout an intracellular mechanism only in infected cells. Li et al. (1972) also reported a virus inhibition by paolins from clams that takes place in cells. Oyster haemolymph inhibits HSV-1 replication at an early stage of the replication cycle, between 0 and 2 hours after initiation of infection. It may thus interfere with the adsorption process, resulting in inhibition of virus attachment to the cell surface. Because of the low selective index observed due to a high degree of cytotoxicity, we could not determine the mode of action of haemolymph. Nevertheless, we suggest that acellular haemolymph contains different components which could induce cytotoxicity as well as antiviral activity. 
Knowledge of the immune mechanisms activated after viral infection of vertebrates would suggest an interferon-type mechanism. However, the presence of interferons has not yet been observed in invertebrates, except for the interference mechanism in shrimps and insects (Bulet et al., 1999; Chernysh et al., 2002) THIS IS NOT CLEAR. Two antiviral and antitumoral peptides called alloferons have been isolated from the blood of the blow fly Calliphorta vicina (Chernysh et al., 2002). This study showed that the alloferon molecules induced cytokine-like synthesis and were able to modulate the activity of human natural killer cells IS THIS OK?

Despite a high level of cytotoxicity detected in oyster haemolymph, a putative antiviral substance with a potential defence role was detected, and is of potential interest in understanding invertebrate immunity. This study should open the way to more effective veterinary medicine in various cultivated species, both in terms of antiviral therapeutic agents and the identification of new targets involved in controlling infections. Further investigations are in progress to confirm the presence of an antiviral molecule in adult Crassostrea gigas.

\section{Acknowledgements}

This work was supported in part by a European Union grant (QLK2-CT 2002-01691) and by a grant from the Poitou-Charentes region. We thank Professor H. Agut (Pitiè Salpétrière hospital, Paris, France) for his valuable advice, and Dr A. Davison for help with the English. We also thank the referees for very useful comments, which helped us to improve the manuscript greatly.

\section{References I HAVE NOT CHECKED THESE}

Arzul, I. and Renault, T., 2002. Herpèsvirus et bivalves marins. Virology, 6, 169-174.

Arzul, I., Renault, T., Thébault, A. and Gérard, A., 2002. Detection of oyster herpesvirus DNA and proteins in asymptomatic Crassostrea gigas adults. Virus Research 84, 151-160.

Azumi, K., Yoshimizu, M., Suzuki, S., Ezura, Y. and Yokosawa, H., 1990. Inhibitory effect of halocyamine, an antimicrobial substance from ascidian hemocytes, on the growth of fish vituses and marine bacteria. Experienta 46, 1066-1068.

Bachère, E., Hervio, D., Mialhe, E. and Grizel, H., 1990. Evidence of neutralizing activity against T3 coliphage in oyster Crassostrea gigas hemolymph. Dev. Comp. Immunol. 14, 261-268.

Bergé, J.P., Bourgougnon, N., Alban, S., Pojer, F., Chermann, J.C., Billaudel, S., Robert, J.M., Durand, P. and Franz, G. 1999. Antiviral and anticoagulant activities of a water soluble compound extracted from marine diatom Haslea ostrearia. Planta Med. 65, 604-609.

Bulet, P., Hetru, C., Dimarcq, J.L. and Hoffmann, D., 1999. Antimicrobial peptides in insects; structure and function. Dev. Comp. Immunol. 23(4-5), 329-344.

Chernysh, S., Kim, S.S., Bekker, G., Pleskach V.A., Filatova N.A., Anikin V.B., Platonov V.G., and Bulet P., 2002. Antiviral and antitumor peptides from insectes. PNAS, 99, 12628-12632.

Damonte, E.B., Neyts, J., Pujol, C.A., Snoeck, R., Andrei, G., Ikeda, S., Witvrouw, M., Reymen, D., Haines, H. and Matulewicz, M.C., 1994. Antiviral activity of a sulphated polysaccharide from the red seaweed Nothogenia fastigiata. Biochem. Pharmacol., 47(12), 2187-2192.

Damonte E.B., Matulewicz M.C., Cerezo A.S. and Coto C.E., 1996. Herpes simplex virus-inhibitory sulfated xylogalactans from the red seaweed Nothogenia fastigiata. Chemotherapy, 42(1), 57-64.

Farley, A.C., Banfield, W.G., Kasnic, G. and Foster, W.S., 1972. Oyster herpes-type virus. Science, 178, 759760.

Hughes, T.K., Blalock, J.E., McKerlie, M.L. and Baron, S., 1981. Cell-produced viral inhibitor: possible mechanism of action and chemical composition. Infect. Immun. 32, 454-457.

Langois, M., Allard, J.P., Nugier, F. and Aymard M., 1986. A rapid and automated colorimetric assay for evaluating the sensitivity of Herpes simplex strains to antiviral drugs. Journal of Biological Standardization 14, 201-211.

Lee, T.G. and Maruyama, S., 1998. Isolation of HIV-1 protease-inhibiting peptides from thermolysin hydrolysate of oyster proteins. Biochem. Bioph. Res. Co. 253, 604-608. 
Li, M.F. and Traxler, G.S., 1972. Antiviral activity of aqueous clam (Mya arenaria) extract on amphibian virus (LT-1)1,2. Can. J. Microbiol. 18(4), 397-402.

Limasset, P., 1961. Observations préliminaires démontrant l'existence d'inhibiteurs du virus de la mosaïque du tabac chez des animaux aquatiques, la plupart marins. CR Acad Sci 252, 3154-3156.

Lowry, O.H., Rosebrough, N.J., Farr, A.L. and Randall, R.J., 1951. Protein measurement with the Folin phenol reagant. J. Biol. Chem. 193, 265-275.

Maier, M.S., Roccatagliata, A.J., Kuriss, A., Chludil, H., Seldes, A.M., Pujol, C.A. and Damonte, E.B., 2001. Two new cytotoxic and virucidal trisulfated triterpene glycosides from the Antarctic sea cucumber Staurocucumis liouvillei. J. Nat. Prod. 64(6), 732-736.

McLaren, C., Ellis, M.N. and Hunter, G.A., 1983. A colorimetric assay for the measurement of the sensitivity of Herpes simplex viruses to antiviral agents. Antivir. Res. 3, 223-234.

Mitta, G., Vandenbulcke, F. and Roch, P., 2000. Original involvement of antimicrobial peptides in mussel innate immunity. FEBS Letters 486, 185-190.

Nakamura, T., Furunaka, H., Miyata,, T., Tokunaga, T., Muta, T., Iwanaga, S., Niwa, M., Takao, T. and Shimonishi, Y., 1988. Tachyplesin, a class of antimicrobial peptide from the hemocytes of the horseshoe crab (Tachypleus tridentatus). J. Biol. Chem. 263(32), 16709-16713.

Pan, J., Kurosky, A., Xu, B., Chopra, A.K., Coppenhave, D.H., Singh, I.P. and Baron, S., 2000. Broad antiviral activity in tissues of crustaceans. Antivir. Res., 48, 39-47.

Prescott, B., Li, C.P., Caldes, G. and Martino, E.C., 1966. Chemical studies of paolin II, an antiviral substance from oysters. Proc. Soc. Exp. Biol. Med. 123(2), 460-464.

Reed, L.J. and Muench, H.A., 1938. A simple method of estimating fifty percent endpoints. Am. J. Hyg. 27:493497.

Renault, T., Torhy, C. and De Kinkelin, P., 1991. Spectrophotometric method for titration of trout interferon and its application of rainbow trout fry experimentally infected with viral haemorrhagic septicaemia virus. Dis. Aquat. Organ. 10, 23-29.

Renault T., Lipart, C. and Arzul, I., 2001. A herpes-like virus infecting Crassostrea gigas and Ruditapes philippinarum larvae in France. J. Fish Dis., 24, 369-376.

Tamamura, H., Kuroda, M., Masuda, M., Otaka, A., Funakoshi, S., Nakashima, H., Yamamoto, N., Waki, M., Matsumoto, A., Lancelin, J.M., Kohda, D., Tate, S., Inagaki, F. and Fujii, N., 1993. A comparative study of the solution stuctures of tachyplesin I and a novel anti-HIV synthetic peptide, T22 ([Try 5,12, Lys 7]polyphemusin II), determined by nuclear magnetic resonance. Biochemica and Biophysica Acta 1163, 209216.

Yasin, B., Pang, M., Turner, J.S., Cho, Y., Dinh, N.N., Waring, A.J., Lehrer, R.I. and Wagar, E.A., 2000. Evaluation of the inactivation of infectious herpes simplex virus by host-defense peptides. Eur J Clin Microbiol Infect Dis 19, 187-194.

Zasloff, M., 2002. Antimicrobial peptides of multicellular organisms. Nature 415, 389-395. 
Olicard et al. 
Olicard et al. 